\title{
Concerns regarding the validity of nutrition self-efficacy questionnaire among Iranian elderly population
}

\author{
Saeed Pahlevan Sharif1,2, Navaz Naghavi ${ }^{1 *}$ (10) and Hamid Sharif $\mathrm{Nia}^{3}$
}

\begin{abstract}
There are some statistical concerns regarding a recently published article which has claimed to develop and psychometrically evaluate an instrument to assess the nutrition self-efficacy among Iranian elderly population.
\end{abstract}

Keywords: Exploratory factor analysis, Construct validity, Reliability, Psychometric

\section{Dear Editor,}

We read with interest the article titled "Nutrition selfefficacy assessment: designing and psychometric evaluation in a community-dwelling elderly population" by Shamsalinia, Ghadimi [1] published in the Journal of Health, Population and Nutrition in 2019. Using mixed methods, the authors developed and psychometrically evaluated an instrument to assess the nutrition self-efficacy among Iranian elderly population. However, there are some serious concerns about the reported results that we intend to share with the editor.

Authors stated that "an EFA using principal components analysis was undertaken to explore the underlying structure of the NSEQ" ([1], P. 5). However, exploratory factor analysis (EFA) and principal component analysis (PCA) are two different methods for different purposes $[2,3]$. Although in some studies EFA and PCA incorrectly have been used interchangeably (See [3]), as Fokkema and Greiff [4] stated "PCA should never be referred to as (exploratory) factor analysis" (p. 401). Indeed, PCA

This comment refers to the article available online at https://doi.org/10.1186/ s41043-019-0203-3.

*Correspondence: navaz.naghavi@taylors.edu.my

${ }^{1}$ Taylor's University, Lakeside Campus, Subang Jaya, Malaysia

Full list of author information is available at the end of the article is more suitable for reducing observed variables into smaller groups of components rather than exploratory extracting underlying factors (latent constructs) [3].

Also, to assess construct reliability, convergent validity and discriminant validity of the instrument, authors claimed to compute composite reliability (CR), average variance extracted (AVE), maximum shared variance (MSV), and average shared variance (ASV) using the results obtained from PCA. While conducting PCA or even EFA to compute CR, AVE, and MSV is questionable, the computed values for the measures are not consistent with the factor loadings reported in the paper [5]. We prepared Table 1 in which CR and AVE values reported in the paper are presented in correspondence with our computed values using the reported factor loadings of the three constructs following the formulas below (See $[5-7])$.

$$
\mathrm{AVE}=\frac{\sum_{i=1}^{n} L_{i}^{2}}{n}
$$

where $i$ is the number of items ranging from 1 to $n . n$ represents total number of items and $L_{i}$ represents the standardized factor loading of item number $i$.

$$
\mathrm{CR}=\frac{\left(\sum_{i=1}^{n} L_{i}\right)^{2}}{\left(\sum_{i=1}^{n} L_{i}\right)^{2}+\left(\sum_{i=1}^{n} e_{i}\right)}
$$

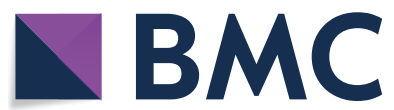

(c) The Author(s) 2022, corrected publication 2022. Open Access This article is licensed under a Creative Commons Attribution 4.0 International License, which permits use, sharing, adaptation, distribution and reproduction in any medium or format, as long as you give appropriate credit to the original author(s) and the source, provide a link to the Creative Commons licence, and indicate if changes were made. The images or other third party material in this article are included in the article's Creative Commons licence, unless indicated otherwise in a credit line to the material. If material is not included in the article's Creative Commons licence and your intended use is not permitted by statutory regulation or exceeds the permitted use, you will need to obtain permission directly from the copyright holder. To view a copy of this licence, visit http://creativecommons.org/licenses/by/4.0/. The Creative Commons Public Domain Dedication waiver (http://creativecommons.org/publicdomain/zero/1.0/) applies to the data made available in this article, unless otherwise stated in a credit line to the data. 
Table 1 Comparing AVE and CR reported in the paper with what we computed based on the reported factor loadings

\begin{tabular}{llllll}
\hline & AVE & $\begin{array}{l}\text { Reported in } \\
\text { the paper }\end{array}$ & \multicolumn{2}{l}{$\begin{array}{l}\text { Computed based on } \\
\text { the factor loadings } \\
\text { reported in the paper }\end{array}$} \\
\cline { 3 - 6 } & CR & AVE & CR \\
\hline Adherence efficacy & 0.577 & 0.901 & 0.260 & 0.829 \\
Preventive behaviors & 0.514 & 0.912 & 0.246 & 0.763 \\
Information effectiveness & 0.636 & 0.913 & 0.291 & 0.662 \\
\hline
\end{tabular}

$C R$ composite reliability, AVE average variance extracted

where $i$ denotes the number of items ranging from 1 to $n$. $n$ represents total number of items and $L_{i}$ represents the standardized factor loading of the item number $i . e_{i}$ is the unexplained variance of item number $i$ by the construct.

As it is shown, none of the computed AVE values meet the convergent validity threshold of AVE greater than 0.5 . Moreover, contrarily to the claimed statement in the paper, CR of information effectiveness is below 0.7 deviating from the construct reliability requirement. Therefore, in contrast to the authors' claim, this study has failed to introduce a reliable construct to measure nutrition self-efficacy among Iranian elderly population.

Besides, our concern continues further to the reported ASV and MSV. Shared variance is the square of the correlation between any two constructs. Therefore, ASV of a construct is the mean of the square of the correlation between the construct and other constructs. Also, MVS of a construct is the largest square of the correlation between the construct and other constructs $[6,8]$. In the study by Shamsalinia et al. [1] there are three constructs in the measurement model and accordingly, there are three covariances between the three constructs. As three different MSV values have been reported in the results, each of the MSV values basically is one of the shared variances between two of the constructs. This means that the reported ASV value for each of the three constructs should be the mean of two of the MSV values. In other words, based on the reported MSV values, ASV values should be $0.353,0.355$, and 0.374 which are different from the results reported in the paper (i.e., 0.329, 0.349, and 0.358). There are more concerns about the reported results. For example, rather than reporting both lower bound and upper bound, only one value for the $95 \%$ confidence intervals for Cronbach's alpha is reported. Also, it is not clear what 0.865 and 0.896 are in the Spearman rank-order correlation coefficient table.

The existence of high level of statistical errors in medical journals, intentionally or unintentionally, has been always caused much concern. Construct reliability and validity lie at the heart of competent and effectiveness of an instrument $[9,10]$. Due to the salient statistical errors in assessing the reliability and validity of the construct, it remains a big concern if this construct is valid to be accessed for future research. Moreover, having it published in an open access journal, it amplifies the importance to warn the irreparable damage it may cause. Providing the collected data of the published paper to the reader might be a solution to prevent such manipulations in the future.

\section{Abbreviations}

AVE: Average variance extracted; ASV: Average shared variance; CR: Composite reliability; EFA: Exploratory factor analysis; MSV: Maximum shared variance;

PCA: Principal component analysis.

\section{Acknowledgements}

Not applicable.

Authors' contributions

All authors had active participation in the preparation of the manuscript. All authors read and approved the final manuscript.

Funding

None.

Availability of data and materials

Not applicable.

\section{Declarations}

Ethics approval and consent to participate

Not applicable.

\section{Consent for publication}

Not applicable.

\section{Competing interests}

The authors declare that they have no competing interests.

\section{Author details}

${ }^{1}$ Taylor's University, Lakeside Campus, Subang Jaya, Malaysia. ${ }^{2}$ Global Centre for Modern Ageing, Adelaide, South Australia 5042, Australia. ${ }^{3}$ Amol Faculty of Nursing and Midwifery, Mazandaran University of Medical Sciences, Sari, Iran.

Received: 12 May 2021 Accepted: 3 February 2022

Published online: 17 February 2022

References

1. Shamsalinia A, Ghadimi R, Chafjiri RT, Norouzinejad F, Pourhabib A, Ghaffari F. Nutrition self-efficacy assessment: designing and psychometric evaluation in a community-dwelling elderly population. J Health Popul Nutr. 2019;38(1):38

2. Alavi M, Visentin DC, Thapa DK, Hunt GE, Watson R, Cleary M. Exploratory factor analysis and principal component analysis in clinical studies: which one should you use? J Adv Nurs. 2020;76(8):1886-9.

3. Park HS, Dailey R, Lemus D. The use of exploratory factor analysis and principal components analysis in communication research. Hum Commun Res. 2002;28(4):562-77.

4. Fokkema M, Greiff S. How performing PCA and CFA on the same data equals trouble: overfitting in the assessment of internal structure and some editorial thoughts on it. Eur J Psychol Assess. 2017;33(6):399-402. 
5. Hair JF, Black WC, Babin BJ, Anderson RE. Multivariate data analysis: Pearson new international edition PDF eBook. Upper Saddle River: Pearson Education; 2013.

6. Fornell C, Larcker DF. Evaluating structural equation models with unobservable variables and measurement error. J Mark Res. 1981;18(1):39-50

7. Pahlevan Sharif S, Sharif Nia H. Factor analysis and Structural equation modeling with SPSS and AMOS. Tehran: Jame-e-Negar; 2021.

8. Farrell AM. Insufficient discriminant validity: a comment on Bove, Pervan, Beatty, and Shiu (2009). J Bus Res. 2010;63(3):324-7.

9. Clark LA, Watson D. Constructing validity: basic issues in objective scale development. Washington, DC: American Psychological Association; 2016. p. 187-203.

10. Thanasegaran G. Reliability and validity issues in research. Integr Dissem. 2009;4:1-7.

\section{Publisher's Note}

Springer Nature remains neutral with regard to jurisdictional claims in published maps and institutional affiliations.

- fast, convenient online submission

- thorough peer review by experienced researchers in your field

- rapid publication on acceptance

- support for research data, including large and complex data types

- gold Open Access which fosters wider collaboration and increased citations

- maximum visibility for your research: over $100 \mathrm{M}$ website views per year

At BMC, research is always in progress.

Learn more biomedcentral.com/submissions 